\title{
Light-enhanced antibiotic activity of Brazilian medical plants (Croton campestris A, Ocimum gratissimum $L$ and Cordia verbenaceae $\mathrm{DC}$ )
}

\author{
Edinardo FF Matias ${ }^{\mathrm{a}}$, Karla KA Santos ${ }^{\mathrm{a}}$, José Galberto M Costa ${ }^{\mathrm{b}}$, Henrique DM Coutinho ${ }^{\mathrm{a}}$ \\ ${ }^{a}$ Laboratory of Microbiology and Molecular Biology, University of Region of Cariri, Crato (CE); \\ ${ }^{b}$ Le o Sampaio College, Juazeiro do Norte (CE), Brasil
}

\begin{abstract}
Background: Although broad-band ultraviolet (UV)-A has been described as a therapeutic option for various skin diseases, there are few studies investigating the efficacy of UV-A irradiation in treating diseases related to infectious agents.

Objective: Evaluate the light-enhanced antibacterial activity of Brazilian medical plants, Croton campestris $A$ (Euphorbiaceae), Ocimum gratissimum L. (Lamiaceae), and Cordia verbenaceae DC (Boraginaceae).

Methods: Hexane extracts of Croton campestris A., Ocimum gratissimum L., and Cordia verbenaceae DC were assayed using a UV-A exposure method against strains of Staphylococcus aureus and Escherichia coli. Assays were performed in triplicate with and without exposure to UV-A radiation to test for light-activated or lightenhanced antibacterial activity.

Results: All extracts showed activity against the $S$. aureus strain. Extracts of $O$. gratissimum and $C$. verbenaceae were the most active after exposure to UV-A light, with an increase in antibacterial activity of 140 and $100 \%$, respectively. No extract showed light-activated antibacterial activity against $E$. coli.

Conclusion: C. campestris, O. gravissimum and C. verbenaceae showed light-enhanced antibiotic activity. This suggests that phytochemical investigations may be warranted.
\end{abstract}

Keywords: Croton zehntneri, UV-A, Light-enhanced antibacterial activity, Staphylococcus aureus, Escherichia coli

There is a growing interest in the effects of biologically active compounds isolated from plants in the treatment of diseases caused by microorganisms $[1,2]$. New aspects of the photochemistry and photobiology of natural products have been reviewed $[3,4]$. Many drugs act as photosensitizers in cells by interacting with various cellular components such as lipids, proteins, and nucleic acids. The structural modifications of the cellular components may occur by direct interactions with drugs in excited states or indirectly through reactive oxygen species sensitized by the drugs themselves [5].

Correspondence to: H.D.M. Coutinho, Departamento de Ciências Físicas e Biológicas, Universidade Regional do Cariri URCA, Rua Cel. Antonio Luis 1161, Pimenta 63105-000, Crato (CE), Brazil. E-mail addresses: hdmcoutinho@gmail.com
The use of different modalities of ultraviolet (UV)-A phototherapy is an interesting approach in the treatment of connective tissue diseases and related disorders [6].

An increasing number of natural products from plants have been shown to exhibit light-mediated biological activity against viruses, microorganisms, cells, and insects [7]. Although there is a great amount of published data regarding the antimicrobial properties of medicinal plants, there is little information on light-activated biological activities from this natural resource, which could represent an interesting source of photosentizers $[8,9]$.

The species Croton campestris is a shrub that is endemic to Brazil, and which is utilized in popular medicine where it is used to combat various diseases [10]. Ocimum gratissimum $L$. is an aromatic sub shrub 
from Asia and Africa [11]. The essential oil from the leaves of this species has shown antimicrobial activity against various microorganisms [11-13]. The species of the genus Cordia are found in all tropical and subtropical regions [14]. The crude extract of the aerial part is utilized by indigenous people against inflammatory processes with topical use [14].

Many medicinal plants contain substances that can evoke adverse reactions, requiring a rigorous control of the quality of cultivation, collection of the plants, extraction of their constituents, and up to the preparation of the final medication [15]. Focusing on the concept of photochemistry and photochemotherapy, we examined here three potentially useful Brazilian medicinal plants and found that their extracts have light-mediated antimicrobial activities.

In this study, we investigated light-enhanced antibiotic activity in natural products with antibacterial activities from plants used medicinally in Brazil. We tested hexane extracts of Croton campestris A., Ocimum gratissimum $L$. and Cordia verbenaceae $D C$ as sources of photocompounds.

\section{Materials and methods Bacterial strains}

The bacterial strains used were E. coli (ATCC 8538) and S. aureus (ATCC 6538). All strains were maintained on heart infusion agar slants (HIA, Difco Laboratories. Lawrence, USA) and prior to assay, the cells were grown overnight at $37^{\circ} \mathrm{C}$ in brain heart infusion (BHI, Difco Laboratories, Lawrence, USA)

\section{Plant material}

Leaves of Croton campestris, Ocimum gratissimum L., and Cordia verbenaceae DC. were collected in the county of Crato, Ceará State, Brazil. The plant material was identified and a voucher specimen was deposited with the respective identification numbers indicated in Table 1.
Preparation of hexane extract of Croton campestris (HECC), Ocimum gratissimum (HEOG) and Cordia verbenaceae (HECV)

Amounts of $31.2 \mathrm{~g}, 58.82 \mathrm{~g}$, and $31.4 \mathrm{~g}$ of leaves from C. campestris, O. Gratissimum, and $C$. verbenacea, respectively, were dried at room temperature, and powdered. The material was extracted by maceration using one liter of hexane as solvent at room temperature. The homogenate was allowed to stand for 72 hours at room temperature. The extracts were filtered and concentrated under vacuum in a rotary evaporator (model Q-344B- Quimis, Brazil) using a warm-water bath (model Q-214M2 Quimis, Brazil). The plant material yielded 1.74, 2.49, and $1.74 \mathrm{~g}$ of extract, respectively. For the tests, the dry extract material was dissolved in DMSO $(10 \mathrm{mg} / \mathrm{mL})$.

\section{Drugs}

8-MOP was obtained from Sigma Chemical (St. Louis, USA), and dissolved in sterile water. Disks with norfloxacin were obtained from Laborclin, Brazil.

\section{Antibacterial assays}

Assays were performed according to the technique by Lopez et al. [4]. As positive controls, a disk of norfloxacin was used as a standard antibiotic for bacteria with photoactivated properties. 8-Methoxypsoralen $(8-\mathrm{MOP}, 10 \mathrm{mg} / \mathrm{mL})$ in water was utilized as a positive control requiring light for activation. Twenty microliters of each extract were added to blank disks. These disks were placed on the surface of the medium inoculated with bacteria by the spread plate method. To monitor for light-activated antimicrobial activities, two replicate experiments were carried out. One replicate plate was exposed to UV $\operatorname{light}\left(5 \mathrm{~W} / \mathrm{m}^{2}, 320-400 \mathrm{~nm}\right.$ from four Sylvania F20T12BLB lamps, maximum emission at $350 \mathrm{~nm}$ ) for two hours, while the other was kept in the dark. The plates were incubated at $37^{\circ} \mathrm{C}$ overnight. The inhibition zones were determined using a pachymeter and recorded.

Table 1. Botanical families, species, and voucher number of the plants used in this study.

\begin{tabular}{lllll}
\hline Family & Species & Abbreviation & Number & Herbarium \\
\hline Euphorbiaceae & Croton campestris & HECC & $\# 7095$ & UFRN \\
Boraginaceae & Cordia verbenacea & HECV & $\# 044171$ & Prisco Bezerra-UFC \\
Lamiaceae & Ocimum gratissimum & HEOG & $\# 3978$ & Dárdano Andrade Lima- \\
& & & & URCA \\
\hline
\end{tabular}




\section{Results and discussion}

A substantial light-enhanced antibiotic activity was seen with the three extracts against the $S$. aureus strain but not against the E. coli strain. HEOG and HECV were the extracts that showed the highest photoactivated activity, where bacterial activity mediated by UV-A was increased $140 \%$ and $100 \%$, respectively. No extract was activated against the Gram-negative strain (Table 2). The weak antibacterial activity against Gram-negative bacteria demonstrated in Table $\mathbf{2}$ is ascribed to the presence of an outer membrane with polysaccharide chains serving as barriers to active compounds in the essential oil [16].

Different concentrations of phototoxic compounds in each extract could explain the different results. Many plant substances when exposed to UV or visible light exhibit phototoxicity, where they are referred to as phototoxins or photosensitizers [17]. A large variety of plants and fungi of various families possess phototoxic substances, possibly serving as natural defense agents against insects and nematodes or against predation or herbivory [7, 18-21]. This activity is due to an indirect effect through the production either of free radicals, or with furocumarins, which interact with DNA [22].

Norfloxacin is a broad-spectrum antibiotic of the fluoroquinolone group, used for the treatment of Grampositive and Gram-negative bacterial infections. This antibiotic is phototoxic as demonstrated in our assay [23]. The antibiotic activity was enhanced mainly against $E$. coli $(134.5 \%)$, possibly due the capacity of this antibiotic to interact and photoreact with systems of medium polarity and proticity such as the membrane systems of Gram-negative bacteria [24].

Besides the enhancement of the light-mediated activity of the extracts, these activities were lower than that observed with 8-MOP (Table 2). However, these results indicate the phototoxic potential of these extracts and highlight the necessity of more studies to evaluate the possible applications of these natural products in phototherapy. This work is the first report of a light-enhanced antibiotic effect of natural products from $C$. campestris, $O$. gratissimum and $C$. verbenaceae. No substance with this property has been isolated from these extracts, which indicates the need for more studies on the phototoxic activity of the compounds from these plant extracts.

Compounds such as polyenes, thiophenes, thiarubrines, quinones, alkaloids, furochromones and porphyrins are widely distributed in various botanical families, such as Asteraceae, Hypericaceae, Apocynaceae, Papaveraceae, Rubiaceae, Liliaceae, Rutaceae, Moraceae, Apiaceae, Euphorbiaceae, Lamiaceae, and Boraginaceae, among others [7]. Some compounds with phototoxic activity have already been shown to have biological activity when photoactivated. Hypericin and hypocrelin, isolated from Hypericum perforatum and Hypocrella bambuase, respectively, have shown anti-HIV and antitumor activity [7], while various studies have demonstrated antibacterial activity with UV light activation [19, 21].

In conclusion, the present results demonstrate that light can be utilized to enhance the antimicrobial activity of phytoconstituents present in hexane extracts of the species $C$. campestris, $O$. gratissimum, and C. verbenaceae. Further phytochemical investigations are warranted to determine if these plants could serve as a source of natural medicine with photoactivity.

The authors have no conflict of interest to report.

Table 2. Diameter of inhibition zones ( $\mathrm{mm} \pm \mathrm{SD}$ ) derived of light-enhanced antimicrobial activity of hexane extracts from Croton campestris, Ocimum gratissimum and Cordia verbenaceae.

\begin{tabular}{lllclcr}
\hline & \multicolumn{3}{c}{ SA6538 } & & \multicolumn{2}{c}{ EC8539 } \\
\cline { 2 - 7 } & UV- & UV+ & Enhancement (\%) & UV- & UV+ & Enhancement (\%) \\
\hline HECC & $6 \pm 2$ & $9 \pm 0,5$ & 50 & $5 \pm 0$ & $5 \pm 0$ & 0 \\
HEOG & $5 \pm 0$ & $12 \pm 1$ & 140 & $5 \pm 0$ & $5 \pm 0$ & 0 \\
HECV & $5 \pm 0$ & $10 \pm 0$ & 100 & $5 \pm 0$ & $5 \pm 0$ & 0 \\
NOR $^{\text {a }}$ & $26 \pm 1$ & $35.5 \pm 4.5$ & 36.5 & $14.5 \pm 2$ & $34 \pm 5$ & 134.5 \\
8 MOP $^{b}$ & $7.5 \pm 0.5$ & $26 \pm 2$ & 246.6 & $5 \pm 0$ & $18 \pm 0$ & 260 \\
\hline
\end{tabular}

HECC: Hexane extract of Croton campestris, HEOG: Hexane extract of Ocimum gratissimum, HECV: Hexane extract of Cordia verbenacea, UV: without UV irradiation, UV+: with UV irradiation; -: no inhibition, a Norfloxacin (10 mg/disk): positive standard; b8MOP: Methoxy psoralen $(10 \mathrm{mg} / \mathrm{mL})$. 


\section{References}

1. Cordell GA, Beecher CWW, Pezzuto JM. Can ethnopharmacology contribute to the development of new anticancer drugs? J Ethnopharmacol. 1991; 32: 117-33.

2. Austin DJ, Kristinsson KG, Anderson RM. The relationship between the volume of antimicrobial consumption in human communities and the frequency of resistance. Proc Natl Acad Sci USA. 1999; 96: 1152-6.

3. Dalla-Via L, Magno SM. Photochemotherapy in the treatment of cancer. Curr Med Chem. 2001; 8:1405-18.

4. Lopez A, Hudson JB, Towers GHN. Antiviral and antimicrobial activities of Colombian medicinal plants. J Ethnopharmacol. 2001; 77:189-96.

5. Violla G, Dall'aque F. Photosensitization of biomolecules by phenothiazine derivatives. Curr Drug Targets. 2006; 7:1135-54.

6. Breuckmann F, Gambichler T, Altmeyer P, Kreuter A. UVA/UVAI phototherapy and PUVA photochemotherapy in connective tissue diseases and related disorders: a research based review. BMC Dermatol. 2004; 4:11.

7. Towers GHN, Page J, Hudson JB. Light-mediated biological activities of natural products from plants and fungi. Curr Org Chem. 1997; 1:395-414.

8. Boonyatavej S, Hayodom M, Praruggamo S, Veerachato G, Pyramann K. Phytochemical screening tests in Thai medicinal plants III. J Sci Res. 1983; 8:93.

9. Tip-pyang S, Sathanasaiwapak S, Kokpol U, Phuwapraisirisan P. Antibacterial flavonoids from Boesenbergia pandurata. ACGC Chem Res Commun. 2000; 10:21-6.

10. Corrêa MP. Dicionário das plantas úteis do Brasil (in Portuguese). Rio de Janeiro: Ministério da Agricultura/ Instituto Brasileiro de Desenvolvimento Florestal. 1975.

11. Martins JR, Alvarenga AA, Castro EM, Silva APO, Oliveira C, Alves E. Leaf anatomy of alfavaca-cravo plants cultivated under colored nets. Cienc Rural. 2008; 39:82-7.

12. Ueda-Nakamura T, Mendonça-Filho RR, MorgadoDíaz JA, Korehisa Maza P, Prado Dias Filho B, Aparício Garcia Cortez D, et al. Antileishmanial activity of Eugenol-rich essential oil from Ocimum gratissimum.
Parasitol Int. 2006; 55:99-105.

13. Matasyoh LG, Matasyoh JC, Wachira FN, Kinyua MG, Muigai AWT, Mukiama TK. Chemical composition and antimicrobial activity of the essential oil of Ocimum gratissimum L. growing in Eastern Kenya. Afr J Biotechnol. 2007; 6:760-5.

14. Bayeux MC, Fernandes AT, Foglio MA, Carvalho JE. Evaluation of the antiedematogenic activity of artemetin isolated from Cordia curassavica DC. Braz J Med Biol Res. 2002; 35: 1229-32.

15. Turolla MSR, Nascimento ES. Toxicological information of some herbal medicines used in Brazil. Rev Bras Cienc Farm. 2006; 42:289-306.

16. Mann CM, Cox SD, Markham JL. The outer membrane of Pseudomonas aeruginosa NCTC6749 contributes to its tolerance to the essential oil of Melaleuca alternifolia (tea tree oil). Lett Appl Microbiol. 2000; 30:294-7.

17. Coutinho HDM, Costa JGM, Lima EO, Siqueira JP Jr. In vitro phototoxic activity of Eugenia jambolana L. and Hyptis martiusii Benth. J Photochem Photobiol B: Biology. 2009; 96:63-5.

18. Berembaum M. Phototoxicity of plant secondary metabolites: insect and mammalian perspectives. Arch Insect Biochem Physiol. 1995; 29:119-34.

19. Cheeptham N, Towers GHN. Light-mediated activities of some Thai medicinal plant teas. Fitoterapia. 2002; 73:651-62.

20. Kang SJ, Kim SH, Liu P, Jovel E, Towers GHN. Antibacterial activities of some mosses including Hylocomium splendens from south western British Columbia. Fitoterapia. 2007; 78: 373-6.

21. Taylor RS, Manadhar NP, Towers GHN. Screening of selected medicinal plants of Nepal for antimicrobial activities. J Ethnopharmacol. 1995; 46:153-9.

22. Foote CS. Definition of type I and type II photosensitized oxidation. Photochem Photobiol. 1991; 54:659.

23. Ray RS, Agrawal N, Misra RB, Farooq M, Hans RK. Radiation-induced in vitro phototoxic potential of some fluoroquinolones. Drug Chem Toxicol. 2006; 29:25-38.

24. Bilski P, Martinez LJ, Koker EB, Chignell CF. Influence of solvent polarity and proticity on the photochemical properties of norfloxacin. Photochem Photobiol 1998; 68:20-24. 